\title{
FAKTOR-FAKTOR YANG MEMPENGARUHI HASIL BELAJAR SISWA PADA MATA PELAJARAN IPS TERPADU KELAS VII
}

\author{
Weldi Rosita Rabbi Rewa \\ e-mail:weldi@gmail.com \\ Ninik Indawati \\ e-mail:ninik@unikama.ac.id \\ Auliana Farrabanie Al Arsy \\ e-mail:auliana@unikama.ac.id
}

(Program Studi Pendidikan Ekonomi, Fakultas Ekonomika dan Bisnis, Universitas Kanjuruhan, Malang)

\begin{abstract}
Learning outcomes are a reflection of the level of success or achievement of the objectives of the learning process that has been carried out and culminated with an evaluation which is then measured using a value or number. This study aims to determine the effect of the implementation of the 2013 curriculum and the full day school system on student learning outcomes in Integrated Social Sciences subjects in VII grade SMP Negeri 17 Malang both simultaneously (simultaneously) or individually (partially). This research is an ex-post facto type and uses a quantitative approach. The population in this study amounted to 168 students of class VII of SMP Negeri 17 Malang with sampling using probability sampling techniques of 70 students. Data collection techniques in this study using questionnaires, interviews and documentation. The results of this study indicate that there is a positive or significant simultaneous effect between the implementation of the 2013 curriculum and the full day school system on student learning outcomes in integrated social studies subjects in class VII SMP 17 Malang. There is a positive or partially significant effect between the implementation of the 2013 curriculum and the full day school system on the learning outcomes of Social Sciences Integrated Class VII SMP Negeri 17 Malang.
\end{abstract}

Keywords : Implementation of 2013 Curriculum, Full Day School System, Learning Outcomes.

\begin{abstract}
Abstrak: Hasil belajar merupakan cerminanan tingkat keberhasilan atau pencapaian tujuan dari proses belajar yang telah dilaksanakan dan puncaknya diakhiri dengan evaluasi yang kemudian diukur menggunakan nilai atau angka. Penelitian ini bertujuan untuk mengetahui pengaruh implementasi kurikulum 2013 dan sistem full day school terhadap hasil belajar siswa pada mata pelajaran IPS Terpadu kelas VII SMP Negeri 17 Malang baik secara bersama-sama (simultan) atau sendiri-sendiri (parsial). penelitian ini termasuk jenis expost-facto dan menggunakan metode pendekatan kuantitatif. Populasi dalam penelitian ini berjumlah 168 siswa kelas VII SMP Negeri 17 Malang dengan pengambilan sampel menggunakan teknik probability sampling sebanyak 70 siswa. Teknik pengumpulan data dalam penelitian ini menggunakan kuesioner, wawancara dan dokumentasi. Hasil penelitian ini menunjukkan bahwa terdapat pengaruh positif atau signifikan secara simultan antara implementasi kurikulum 2013 dan sistem full day school terhadap hasil belajar siswa pada mata pelajaran IPS Terpadu kelas VII SMP Negeri 17 Malang. Terdapat pengaruh positif atau signifikan secara parsial antara implementasi kurikulum 2013 dan sistem full day school terhadap hasil belajar IPS Terpadu Kelass VII SMP Negeri 17 Malang
\end{abstract}

Kata kunci : Implementasi Kurikulum 2013, Sistem Full Day School, Hasil Belajar. 


\section{PENDAHULUAN}

Ditengah perubahan zaman yang semakin modern diperlukan suatu pendidikan yang dirancang berdasarkan kebutuhan nyata dilapangan. Sekolah harus mampu mempersiapkan lulusan pendidikan yang mampu menghadapi tantangan globalisasi yang semakin maju. salah satu upaya yang dilakukan oleh guru adalah dengan meningkatkan hasil belajar. Hasil belajar siswa adalah cerminan dari tingkat keberhasilan atau pencapaian tujuan dari proses belajar yang telah dilaksanakan dan puncaknya diakhiri dengan suatu evaluasi. Ada banyak faktor yang mempengaruhi hasil belajar siswa, beberapa dari faktor tersebut antara lain implementasi kurikulum dan sistem full day school.

SMP Negeri 17 Malang sudah mengimplementasikan kurikulum 2013 sejak tahun 2013 dan menerapkan sistem full day school sejak tahun 2015. Sebagai contoh dalam implementasi kurikulum 2013 yaitu pada mata pelajaran IPS Terpadu di kelas VII dimana guru menggaubungkan dua metode yakni ceramah dan diskusi dengan menggunakan pendekatan saintifik. dengan adanya implementasi kurikulum 2013 dan sistem full day school ini pihak sekolah mengharapkan hasil belajar siswa dapat mengembangkan kemampuan yang mereka miliki. Berdasarkan observasi yang dilakukan peneliti banyak siswa yang kurang aktif atau pasif dalam diskusi karena siswa diberi kebebasan dalam menggunakan media belajar seperti buku paket, LKS, dan internet (jika diperlukan) dalam menyelesaikan tugas. guru mata pelajaran IPS Terpadu dalam proses pembelajaran masih belum maksimal ini terlihat ketika guru masih belum mampu menyusun rencana pembelajaran dengan baik. hal ini mungkin disebabkan oleh perubahan kurikulum sehingga menyulitkan penyelenggara pendidikan tingkat sekolah dalam penyiapan penyesuaian.

Adapun tujuan dalam penelitian ini sesuai dengan latar belakang dan rumusan masalah untuk mengetahui faktor-faktor yang mempengaruhi hasil belajar siswa. peneliti berharap dengan adanya penelitian ini diharapkan SMP Negeri 17 Malang mampu meningkatkan hasil belajar siswa berdasarkan faktor-faktor yang telah dijelaskan oleh peneliti.penelitian ini berjudul "Faktor-faktor Yang Mempengaruhi Hasil Belajar Siswa Pada Mata Pelajaran IPS Terpadu Kelas VII SMP Negeri 17 Malang.

\section{TINJAUAN PUSTAKA Hasil Belajar}

Salah satu tolak ukur untuk mengetahui tingkat keberhasilan suatu proses pembelajaran adalah dengan melihat hasil belajar yang diperoleh oleh siswa. Hasil belajar adalah cerminan tingkat keberhasilan atau pencapaian tujuan dari proses belajar yang telah dilaksanakan dan puncaknya diakhiri dengan evaluasi yang kemudian dituangkan dalam bentuk nilai atau angka. Sudjana (2014:3) menyatakan hasil belajar siswa pada hakikatnya adalah perubahan tingkah laku sebagai hasil belajar dalam pengertian yang lebih luas mencakup bidang kognitif, afektif, dan psikomotorik. Dimyati dan Mudjino (2013:3-4) juga menyebutkan hasil belajar merupakan hasil dari suatu interaksi tindak belajar dan tindak mengajar yang diakhir dengan proses evaluasi. Benyamin Bloom (2014:22) mengemukakan secara garis besar membagi hasil belajar menjadi tiga ranah, yaitu: ranah kognitif, ranah afektif dan ranah psikomotorik.

\section{Implementasi Kurikulum 2013}

Oemar Hamalik (2010:238) mendefenisikan implementasi kurikulum 2013 adalah penerapan atau pelaksanaan program kurikulum yang telah dikembangkan dalam tahap sebelumnya, kemudian diujicobakan dengan pelaksanaan dan pengelolaan, sambil dikukan penyesuaian terhadap situasi lingkungan dan karakteristik peserta didik baik perkembangan intelektual, emosional dan fisiknya. Mulyasa (2014:12) menjelaskan bahwa kurikulum 2013 lebih fokus dan berangkat dari karakter serta kompetensi yang akan dibentuk, baru memikirkan untuk mengembangkan tujuan yang akan dicapai. semua komponen lebih diarahkan pada pembentukan karakter dan kompetensi peserta didik. 
Kerangka dasar kurikulum; 1) Landasan Filosofis; 2) Landasan Teoritis; 3) Landasan Yuridis. Struktur kurikulum terdiri dari; 1) Kompetensi Inti; 2) Mata Pelajaran; 3) BebanBelajar; 4) Kompetensi Dasar. Implementasi kurikulum berfokus pada perencanaan pembelajaran, pelaksanaan pembelaran dan penilaian pembelajaran.

\section{Sistem Full Day School}

Sistem full day school dapat diartikan dengan sekolah sepanjang hari. Peraturan Mentri No. 23 Tahun 2017 pasal 2 tentang sistem full day school merupakan proses belajar mengajar yang dilaksanakan 8 jam dalam 1 hari atau 40 jam selama 5 hari (senin-jumat) dalam 1 minggu. Dalam sistem full day school ada tiga ranah yang dikembangkan yaitu ranah kognitif atau pengetahuan, ranah afektif atau sikap dan ranah psikomorik atau keterampilan. dengan adanya pembagian ranah tersebut maka siswa diharapkan mampu memjadi manusia yang kreatif, kritis dan memiliki keterampilan dalam mengambil sebuah keputusan. Dalam sistem full day school ini siswa mendapatkan keuntungan secara akademik dimana lamanya waktu belajar siswa dapat menambah pengalaman dan keuntungan secara sosial. siswa juga akan lebih banyak belajar dari pada bermain karena adanya waktu belajar yang lama dalam kelas dan selalu berada dalam pengawasan guru. ada beberapa faktor yang dapat menunjang sistem full day school yaitu: kurikulum, sarana dan prasarana, sumber daya manusian (SDM).

\section{METODE}

Penelitian ini menggunakan jenis ex-post-facto, karena penelitian ini berhubungan dengan variabel yang sudah terjadi sehingga peneliti tidak perlu memberikan perlakuan pada variabel yang diteliti. penelitian ini menggunakan pendekatan kuantitatif yang dianalisis menggunakan analisis statistic dengan bantuan SPSS versi 22.00 for windows. Analaisis data merupakan salah satu kegiatan penelitian berupa proses penyusanan dan pengolahan data guna menafsirkan data yang diperoleh. Populasi dari penelitian ini adalah siswa kelas VII SMP Negeri 17 Malang Tahun Ajaran 2018/2019 yang terdiri dari 8 kelas yaitu: kelas VIIA, VIIB, VIIC, VIID, VIIE, VIIF, VIIG, dan VIIH yang berjumlah 168 siswa. pengambilan sampel yang digunakan peneliti adalah probability sampling, yaitu teknik pengambilan sampel yang memberikan peluang yang sama bagi setiap anggota populasi untuk dipilih menjadi sampel (Sugiono 2017:82). sedangkan teknik probability sampling yang digunakan adalah simple rondom sampling yaitu pengambilan sampel tanpa memandang strata yang ada dalam populasi tersebut.

\section{PEMBAHASAN}

Penelitian ini terdiri dari dua variabel bebas yaitu implementasi kurikulum 2013 dan sistem full day school yang diduga memiliki pengaruh terhadap hasil belajar siswa pada mata pelajaran IPS Terpadu kelas VII SMP Negeri 17 Malang. Deskripsi dari hasil penelitian ini didapat dari data yang menggunakan instrumen penelitian dengan skala likert. pemaparan tersebut meliputi beberapa variabel diantaranya, yaitu: implementasi kurikulum 2013 (X1) sistem full day school (X2) dan hasil belajar

yang mencakup mean, median, standar deviation, skor minimum, dan skor maksimum.

Berdasarkan hasil penelitian statistik dengan menggunakan SPSS 22.00 for windows diperoleh tabel Anova yang menunjukkan uji F statistik. adapun hasil dari uji F pada tabel Anova sebagai berikut:

Tabel 1. Hasil Uji F

ANOVAa

Sum of Mean




\begin{tabular}{|c|c|c|c|c|c|c|}
\hline \multicolumn{2}{|c|}{ Model } & Square & \multicolumn{2}{|c|}{ Square } & $\mathrm{F}$ & Sig \\
\hline 1 & $\begin{array}{l}\text { Reg } \\
\text { Ress } \\
\text { Ion }\end{array}$ & 207.762 & 2 & 103.881 & $\begin{array}{r}3.75 \\
2\end{array}$ & $.029^{b}$ \\
\hline & $\begin{array}{l}\text { Resi } \\
\text { dua } \\
\text { l }\end{array}$ & $\begin{array}{r}1855.11 \\
0\end{array}$ & 67 & 27.688 & & \\
\hline & $\begin{array}{l}\text { Tot } \\
\text { al }\end{array}$ & $\begin{array}{r}2062.87 \\
1\end{array}$ & 69 & & & \\
\hline
\end{tabular}

a. Dependent Variable: Hasil Belajar

b. Predictors: (constant), Sistem Implementasi Kurikulum ( $\left.X_{1}\right) 2013$ dan Sistem Full Day School $\left(\mathrm{X}_{2}\right)$

Sumber: Hasil pengolahan data SPSS Versi 22.00 for windows (2019)

Berdasarkan tabel 1 diatas nilai F sebesar 3.752 dengan tingkat signifikan 0.029, karena tingkat signifikan lebih kecil dari 0.05 maka $\mathrm{H}_{1}$ diterima yang artinya implementasi kurikulum $2013\left(\mathrm{X}_{1}\right)$ dan sistem full day school $\left(\mathrm{X}_{2}\right)$ secara bersama-sama (simultan) berpengaruh positif atau signifikan terhadap hasil belajar $(\mathrm{Y})$.

Hasil perhitungan statistic dengan bantuan SPSS 22.00 for windows diperoleh tabel coefficient yang menunjukkan uji $\mathrm{t}$ (parsial). uji $\mathrm{t}$ digunakan untuk menguji signifikan pengaruh dari setiap variabel independen yaitu implementasi kurikulum $2013\left(\mathrm{X}_{1}\right)$ dan sistem full day school (X2) secara sendiri-sendiri (parsial) terhadap variabel dependen yaitu hasil belajar $(\mathrm{Y})$. hasil dari uji $\mathrm{t}$ dapat dilihat pada tabel 2.

\begin{tabular}{lrrr}
\multicolumn{2}{c}{ Coefficients } & & \\
& & $\mathrm{T}$ & Sig. \\
& Beta & & \\
\hline (Constant) & & 12.763 & .000 \\
IMPLEMENTASI & & 2.043 & .045 \\
KURIKULUM 2013 & .408 & & \\
\hline SISTEM FULL DAY & -.544 & -2.723 & .008 \\
SCHOOL & & &
\end{tabular}

a. Dependent Variable: Hasil Belajar

Sumber: Hasil Pengolahan data SPSS Versi 22.00 for windows (2019)

Berdasarkan tabel 2 hipotesis penelitian untuk menguji hipotesis kedua (H2) adalah sebagai berikut: diperoleh $\mathrm{t}$ hitung sebesar 2.043 dengan nilai signifikan sebesar 0.045 lebih kecil dari 0.05 yang artinya terdapat pengaruh positif atau signifikan antara implementasi kurikulum 2013 (X1) terhadap hasil belajar $(\mathrm{Y})$. Hasil analisis hipotesi ketiga (H3) adalah sebagai berikut: diperoleh nilai $\mathrm{t}$ hitung sebesar - 2.723 dengan nilai signifikan sebesar 0.008 lebih kecil dari 0,05 yang artinya tidak terdapat pengaruh positif dan signifikan antara sistem full day school (X2) terhadap hasil belajar (Y) tetapi terdapat pengaruh negatif dan signifikan antara full day school (X2) terhadap hasil belajar (Y).

Berdasarkan hasil penelitian, dapat diketahui bahwa terdapat pengaruh yang posiitif atau signifikan secara bersama-sama (simultan) antara variabel independen yaitu implementasi kurikulum 2013 (X1) dan sistem full day school (X2) terhadap variabel dependen yaitu hasil belajar (Y) siswa pada mata pelajaran IPS Terpadu kelas VII SMP Negeri 17 Malang tahun ajaran 2018/2019 dengan nilai F-hitung 3.752 dengan tingkat signifikan sebesar 0.029. karena tingkat signifikan lebih kecil dari 0.05, maka H1 diterima.

Hasil penelitian ini juga menunjukkan bahwa terdapat pengaruh positif atau signifikan secara parsial antara variabel implementasi kurikulum 2013 (X1) terhadap hasil belajar (Y) pada mata 
pelajaran IPS Terpadu kelas VII SMP Negeri 17 Malang. dapat dilihat pada hasil $\mathrm{t}$ hitung sebesar 2.043 dengan tingkat signifikan sebesar 0.045. Implementasi kurikulum 2013 ini dapat dilihat dari perencanaan pembelajaran, pelaksanaan pembelajara dan penilaian pembelajaran. penelitian ini sejalan dengan hasil penelitian yang dilakukan oleh Fahmi Reza Anzhory (2016) yang menyatakan bahwa ada pengaruh yang signifikan implementasi kurikulum 2013 terhadap hasil belajar siswa pada mata pelajaran Sosiologi kelas X SMA Negeri 01 Batu.

Hasil penelitian yang mendukung hipotesis ketiga yang menunjukkan tidak berpengruh positif dan signifikan terhadap hasil belajar atau terdapat pengaruh negative atau signifikan antara sistem full day school (X2) terhadap hasil belajar (Y). terbukti dari hasil perhitungan statistic yang diperoleh dengan nilai $t$ hitung -2.723 dengan tingkat signifikan 0.008. Hal ini dapat dilihat dari kurikulum, sarana dan prasaran, dan sumber daya manusia yang menjadi faktor penunjang program sistem full day school. Hasil penelitian ini sejalan dnelitian yang dilakukan oleh Dilan Melan Sari (2018) yang menyatakan ada pengaruh yang signifikan antara program full day school terhadap prestasi belajar siswa kelas XI SMA Global Madani.

\section{KESIMPULAN}

Berdasarkan hasil penelitian yang telah dilakukan oleh peneliti mengenai implementasi kurikulum 2013 dan sistem full day school terhadap hasil belajar siswa pada mata pelajaran IPS Terpadu kelas VII SMP Negeri 17 Malang maka dapat disimpulkan bahwa terdapat pengaruh positif atau signifikan secara simultan antara variabel independen yaitu implementasi kurikulum 2013 (X1) dan sistem full day school (X2) terhadap variabel dependen yaitu hasil belajar (Y). Terdapat pengaruh positif atau signifikan secara parsial antara implementasi kurikulum 2013 terhadap hasil belajar siswa. Terdapat pengaruh negative atau signifikan antara sistem full day school terhadap hasil belajar. Berdasarakan kesimpulan diatas peneliti dapat memberikan saran yang dapat menambah wawasan bagi pelaksana kurikulum 2013 dalam hal ini kepala sekolah, kepala kurikulum dan para guru.

Pertama, bagi sekolah penelitian ini dapat dijadikan bahan masukan dalam mengembangkan program selanjutnya. kedua, bagi kepala sekolah diharapkan penelitian ini dapat memberikan informasi ilmiah tentang implementasi kurikulum 2013 dan sistem full day school. Ketiga, bagi guru dapat digunakan sebagai upaya dalam pengembangan dalam upaya meningkatkan hasil belajar siswa pada mata pelajaran IPS Terpadu kelas VII SMP Negeri 17 Malang dan menciptakan pendidikan yang berkualitas dan bermutu.

\section{DAFTAR PUSTAKA}

Anwar, R. (2014). Hal-hal yang mendasari penerapan kurikulum 2013. Humaniora.

Arifin.2012. Konsep dan Model Pengembangan Kurikulum. Bandung: PT Remaja Rosdakarya Asep Saepul Hamdi dan E. Baharuddin. 2014. Metode Penelitian Kualitatif. Yogyakarta: Deepublish. Azizah, Annisa Nurul. (2014). Program Full Day School Dalam Pengembangan Kurikulum Siswa Kelas IV di SDIT Insan Utama 127 Bantul. Bloom, Benyamin. 2014. Hasil Belajar. Jakarta: Bumi Aksara

Dimyati dan Mudjino. 2013. Belajar dan Pembelajaran. Bandung: Rineka Cipta.

Hamalik, Oemar. 2010. Kurikulum dan Pembelajaran. Jakarta: Bumi Aksara.

Hasan, Nor. 2010. Full Day School (Model Alternatif Pembelajaran Bahasa Asing). Vol.1. No.1 Hal: $109-118$

Hasanah,U. N. (2017). Evaluasi implementasi Kurikulum 2013 Pada SMA Pilot Project di Kota Yogyakarta. Jurnal Akuntabilitas Manajemen Pendidikan.

Kementerian Pendidikan dan Kebudayaan. (2014). Materi Pelatihan Guru Implementasi Kurikulum 2013 Tahun 2014 SD Kelas IV. Jakarta: Kementrian Pendidikan dan Kebudayaan.

Mulyasa. 2014. Pengembangan dan Implementasi Kurikulum 2013. Bandung: PT Remaja Rosdakarya. 
Slameto. 2013. Belajar dan Faktor-faktor Yang Memepengaruhi. Jakarta: Rineka Cipta.

Sudjana, Nana. 2014 Penilaian Hasil Proses Belajar Mengajar. Bandung: Remaja Rosdakarya.

Sugiono. 2014. Metode Penelitian Pendidikan Pendekatan Kuantitatif, Kualitatif dan R\&D. Bandung: Alfabeta.

Soapatty, L. (2014). Pengaruh Sistem Sekolah Sehari Penuh (Full Day School) Terhadap Prestasi Akademik Siswa SMP Jati Agung Sidoarjo.

Kajian Moral dan Kewarganegaraan, hal. 719-71

Undang-undang No. 20 Tahun 2003,Tentang Sistem Pendidikan Nasional. Dirjen Dikti Depdiknas. Jakarta. 